\title{
The Effect of Wealth Inequality on Higher Education Outcomes: A Critical Review
}

\author{
Emily Rauscher'1, William Elliott III ${ }^{2}$ \\ ${ }^{1}$ Department of Sociology, University of Kansas, Lawrence, USA \\ ${ }^{2}$ School of Social Welfare, University of Kansas, Lawrence, USA \\ Email: emily.rauscher@ku.edu, welliott@ku.edu
}

Received 15 July 2014; revised 18 August 2014; accepted 30 August 2014

Copyright $@ 2014$ by authors and Scientific Research Publishing Inc.

This work is licensed under the Creative Commons Attribution International License (CC BY).

http://creativecommons.org/licenses/by/4.0/

(c) (i) Open Access

\begin{abstract}
American society reflects considerable class immobility, much of which may be explained by the wide gaps in college completion rates between economically advantaged and disadvantaged groups of students. First, we discuss the factors that lead to unequal college completion rates and introduce assets as an explanation often ignored by stratification scholars. We then discuss how a legacy of wealth inequality has led to wealthy students having an advantage at the financial aid bargaining table over low-income and minority students. We conclude by discussing how assetbuilding policies such as children's savings accounts offer a potential policy strategy to alter the distributional consequences of the current financial aid system and help level the playing field.
\end{abstract}

\section{Keywords}

Inequality, Higher Education, Wealth, Policy, Children's Savings Accounts

\section{Introduction}

Most Americans believe that the United States provides equality of opportunity. In fact, intergenerational mobility in the U.S. is lower than in most other developed countries (Ermisch, Jänttii, \& Smeeding, 2012; Hertz et al., 2007; Jäntti et al., 2006). Using intergenerational data from ten developed countries, Ermisch et al. (2012) find a stronger association between parental education and children's outcomes-including economic, educational, cognitive, physical, and socio-emotional measures - in the U.S. than in any other country examined. Similarly, Jäntti et al. (2006) find stronger intergenerational transmission of earnings in the U.S. than in the U.K. and Nordic countries.

Education plays a central role in the intergenerational transmission of socioeconomic standing (Blau \& Duncan, 1967). Although education can increase opportunity, how much education one attains depends strongly on 
socioeconomic standing. In other words, education both reduces and reproduces inequality, transmitting advantage from one generation to the next.

Both early and recent research (Hout, 1988; Belman \& Heywood, 1991; Torche, 2011) suggests that a college degree can reduce the importance of social background and increase intergenerational equality. Yet even if they manage to enroll in college, many Americans fail to complete this credential. According to the National Center for Education Statistics (2013), only 59\% of those who entered a four-year institution in 2005 completed a degree within six years. Graduation rates at two-year colleges were even lower. Among those who began an associate's degree or certificate in 2008, only 31\% completed it within one and a half times the normal time required. There are stark class differences, however, in likelihood of completion. Based on data from the 2009 Beginning Postsecondary Students survey (using NCES QuickStats ${ }^{1}$ ), among those with income more than $200 \%$ above the poverty level when they began college in 2003-2004, 55.6\% completed a degree or certificate by 2009. This compares to $46 \%$ for students $151 \%$ - 200\% above the poverty level, $43 \%$ among those $101 \%$ - $150 \%$ above the poverty level, and only $36.8 \%$ among those at or below poverty. Beyond access, therefore, gaps in the likelihood of college completion once enrolled further reproduce inequality.

Kalleberg (2011) highlights the increasing polarization of "good" (secure, well-paying) jobs and "bad" jobs, which offer little security, low-wages, and no benefits. With the increasing scarcity of good jobs available to those without higher education (Kalleberg, 2011; Carnevale et al., 2011), a college degree has become critical for access to jobs that provide a living wage, which Carnevale et al. (2011) set at $\$ 35,000$ a year (150\% of the poverty level for a family of four). For example, Carnevale and his colleagues (2011) find that only $36 \%$ of high school graduates without any college education earn at least a living wage, while $46 \%$ of those with some college and $69 \%$ of college degree holders earn above the living wage cutoff. If the number of good jobs available to those without college education continues to decline (Carnevale et al., 2011), or rising skill demands continue to boost the college wage premium (Autor, 2014), college completion will become even more important for economic security in the future.

Despite evidence that a college degree reduces the importance of parental class and income for life chances (Torche, 2011; Hout, 1984, 1988), parental resources remain strongly related to college completion (Bowen, Chingos, \& McPherson, 2009). Thus, similar to the early findings of Blau and Duncan (1967), while poor students who graduate may enjoy more equal opportunity than they would otherwise, the unequal chances of completing a degree make college graduation an important factor in the intergenerational transmission process (e.g., Carnevale \& Strohl, 2010; Haskins, 2008). In order for education to be an arbiter of intergenerational mobility, therefore, U.S. policy must address the wide gap in educational attainment among different economic classes.

In the sections below we review evidence of the relationship between resources and college completion. In the first section, we outline some of the classic explanations for the intergenerational transmission of college completion. With this background, the second section reviews evidence of an alternative mode of intergenerational transmission: assets. Specifically, an overview of research on effects of children's savings accounts (CSAs) suggests they can increase equality of college completion, in part by reducing our overreliance on student debt financing. We then discuss how assets became so important for college completion in contemporary U.S. society and how asset building policies could help level the playing field.

\section{Classic Explanations for Unequal College Completion Rates}

In this section, we review common explanations for unequal college access and completion, including income, parental education, cultural and social capital, family size and structure, health, and meritocratic explanations, such as ability or intelligence.

\subsection{Parental Income}

Controlling for other factors, such as family assets or liabilities, research suggests family income is significantly related to college completion (Kim \& Sherraden, 2011; Nam \& Huang, 2009). If the parents of an aspiring college graduate earn at or below the poverty level, she will have difficulty financing one year of college, let alone the four or five that may be necessary to complete an undergraduate degree. If money for even the basic necessities of food and housing is difficult to obtain growing up, low-income students may be particularly averse to student loans, further constraining educational choices. This aversion could encourage low-income students to

\footnotetext{
${ }^{1}$ http://nces.ed.gov/datalab/quickstats/default.aspx
} 
opt for a less expensive institution with fewer supports and lower graduation rates (e.g., Carnevale \& Strohl, 2010; Cunningham \& Santiago, 2008) or to balance a heavy workload while enrolled in college (Walpole, 2003). Employment while in school can help finance college but in many cases detracts from both academic and social engagement, making students more likely to drop out and less likely to establish useful social connections with faculty or students (Hamilton, 2013). Complicating these challenges, low income families are more susceptible to financial shocks, including job loss, health emergencies, or medical bills (Acs, Loprest, \& Nichols, 2009; McKernan, Ratcliffe, \& Vinopal, 2009; Pew Charitable Trusts, 2013), which could drive a student out of college and into the workplace to help support her family (e.g., Elliott, 2013a).

In contrast, students from higher-income families enjoy advantages compared to their lower-income counterparts. High income students may take for granted uninterrupted support throughout their college careers. Less likely to have to work to pay for college or support their family, higher-income students enjoy more time for study and extracurricular involvement, thereby strengthening ties to the school and peers and reducing their chances of dropping out (Walpole, 2003). Institutional differences, though often unappreciated, play an important role as well. Higher-income families tend to ensure their children access to well-funded secondary schools, which provide higher quality teachers and more rigorous preparation for college (Condron \& Roscigno, 2003; Card \& Kreuger, 1996; Johnson, 2006). Because their high schools (or tracks within school) often provide stronger academic preparation for college, students from higher-income backgrounds tend to enjoy more options regarding where to attend and may choose a more selective, better quality school with higher retention rates (Carnevale \& Strohl, 2010; Davies \& Guppy, 1997).

At the same time, however, recent research counters the importance of income, suggesting other factors may be better predictors or college completion. For example, evidence by Song \& Elliott (2011) suggests that income does not significantly predict college completion among Hispanic immigrant children. Similarly, Zhan and Sherraden (2011) find that, although income is significantly related to degree completion among white children, the relationship does not hold among black or Hispanic children. Further supporting doubts about the importance of income, evidence suggests that a $25 \%$ or greater decrease in income positively predicts college completion (Elliott, 2013a). Similarly, recent evidence that accounts for variation in family assets suggests income is negatively related to college completion among all (Elliott, 2013b), black (Friedline, Elliott, \& Nam, 2013), and low-to-moderate income children (Elliott, Song, \& Nam, 2013). This negative relationship is counterintuitive, but could reflect a number of patterns, including: 1) the propensity of low-income students to enroll in two-year degree programs, which are easier and less costly to complete; 2) the financial challenge college poses to families whose income is just slightly too high to qualify for means-tested financial aid; and 3) the ability of higher-income parents (who possess more information about the financial aid process) to "game" the system, purposely limiting their income to increase aid eligibility.

These recent findings - that income does not necessarily boost and in some cases negatively predicts college completion-suggest a more complex explanation for unequal college completion rates. Because family income is not educational destiny (Mayer, 1997), policy interventions may be able to increase equality of educational attainment while avoiding the unpopular prospect of income redistribution.

\subsection{Parental Education}

Once a student has gained access, evidence suggests that parental education plays a role in completing college (Bowen et al., 2009). For example, even after adjusting for differences in high school grade point average, SAT or ACT scores, state residency status, race or ethnicity, gender, family income, and the university a student attended, Bowen et al. (2009) find that children of parents with a bachelor's degree were still 6\% more likely to complete a degree within six years than children of parents with no college education. Other evidence suggests that nearly $90 \%$ of first generation students fail to graduate within six years (Greenwald, 2012). Although studying first generation college students, whose parents have no college education, represents a stark contrast, the findings highlight the importance of unequal college graduation rates for low intergenerational mobility in the U.S. (Ermisch et al., 2012).

The association between parental education and children's college completion suggests that parents may help their children navigate the complex process of completing a college degree. For example, educated parents may help their children choose a major that fits both their career goals and ability. Parents with a college education may also provide their children with the interpersonal communication skills necessary for success in college. 
Stephens, Fryberg, Markus, Johnson, \& Covarrubias (2012) find, for example, that first generation students tend to value interdependence, which contradicts the academic norm of independence. Similarly, although children of college educated parents may learn at a relatively young age the distinction between debate and argument or constructive and personal criticism, Greenwald (2012) suggests first generation students can have trouble making those distinctions and therefore struggle in academic settings.

The evidence above suggests parental education may promote college success through interpersonal skills, making it difficult to uncover with quantitative methods. Possibly as a result of how parental education matters, there is conflicting evidence regarding whether it has a causal impact on college completion rates or whether other factors (e.g., parental income, occupational standing, or academic preparation) account for the relationship. Although they do not investigate children's college completion, recent research exploiting natural experiments finds that parental education does increase children's educational achievement (Attewell \& Lavin, 2007; Oreopoulos, Page, \& Stevens 2006). It seems likely that the effects of parental education continue throughout college and even beyond, compounding across generations.

\subsection{Cultural and Social Capital}

Cultural and social capital—-the social cues and cultural norms that higher-status children acquire as part of their socialization into an advantaged class-are often tightly tied to parental education. However, they are conceptually distinct from parental education and represent another explanation for unequal college completion rates. Students who attend elite boarding schools or frequently visit museums, for example, could gain cultural behaviors and valuable social connections regardless of parental education (Khan, 2011; Cookson \& Persell, 1985).

Theoretically, cultural capital should improve educational chances because schools reward students not just for academic ability, but also for culturally "appropriate" knowledge and behavior. Students who acquire forms of cultural knowledge and behavior that are valued by elites typically enjoy higher academic achievement (Bourdieu, 1977; DiMaggio, 1982). Because children acquire cultural capital through parental behaviors and practices (Lareau, 2002, 2003), cultural capital is one way that parents transmit advantages to their children. For example, middle-class parents question and negotiate with their children, making them more comfortable with teachers and other authority figures (Lareau, 2002). Extracurricular activities, more common among middle class children, further boost school engagement and groom students for college applications.

Perhaps most important for college completion, Lareau (2011) found that middle class parents help their children navigate the college experience, giving advice about courses and majors, for example. Thus, beyond parental education, knowledge about navigating college (one form of cultural capital) could make college completion more likely. Supporting this argument, there is evidence that cultural capital improves college achievement and persistence (Wells, 2008; Spenner, Buchmann, \& Landerman, 2005). For example, first generation students have more difficulty performing the "college student role" and more often miss the implicit expectations of professors (Collier \& Morgan, 2008), hindering academic performance.

Distinct from cultural capital, research on the relationship between social capital and college completion emphasizes social engagement explanations for student retention. Extracurricular activities, for example, can improve individual attachment to college and increase the chances of graduating or even continuing on to earn a graduate degree (Tinto, 1987; Walpole, 2003). Not surprisingly, extracurricular participation rates vary by social class (Walpole, 2003); students who must work are less able to participate in social activities. Research also suggests that upper-class students feel more strongly that they belong at an institution than lower-class students (Ostrove \& Long, 2007).

While quantity is important, the quality of social capital also has implications for college success. Sacerdote (2001) capitalizes on random first-year roommate assignments, finding that peer academic ability and grade point average influence individual grade point average. Because students with lower academic success or engagement are more likely to leave college (Tinto, 1987; Wells, 2008), social capital has implications for college retention. The friendships a student forms at college, therefore, can have important implications for college completion (Eckles \& Stradley, 2012) and could be unequal if students befriend others with similarly disadvantaged—or advantaged—social backgrounds.

\subsection{Family Size and Structure}

Because larger families must divide their financial resources among more children, family size represents 
another common explanation for unequal college completion rates. Although research on family size rarely investigates its effects on college completion, it does find that having more siblings reduces individual educational attainment (Steelman, Powell, Werum, \& Carter, 2002). Beyond family size, evidence also suggests that sibling density (the age spacing of siblings) is related to educational achievement and attainment (Powell \& Steelman, 1990; Conley, 2001; Steelman et al., 2002). The number and spacing of siblings, in other words, impacts the share of parental resources (including time and money) available throughout childhood. At the college level, Steelman et al. (2002) find that more siblings dilute parental financial contributions to college costs, which reduces educational attainment. Beyond siblings, other aspects of family structure have implications for college persistence. For example, children with younger fathers are less likely to complete high school and, if they enter college, are less likely to persist there as well (Mare \& Tzeng, 1989). Family size and structure therefore provide another mechanism for the intergenerational transmission of inequality.

\subsection{Mental and Physical Health}

Though perhaps a less common explanation, research consistently finds a relationship between educational attainment and health, even as early as in utero (Behrman \& Rosenzweig, 2004; Black, Devereux, \& Salvanes, 2007; Oreopoulos, Stabile, Roos, \& Walld, 2008; Royer, 2009; Conley, Strully, \& Bennett, 2003; see Eide \& Showalter, 2011 for a review; Almond, 2006; Almond \& Mazumder, 2005; Almond, Edlund, \& Palme, 2009). Interestingly, Nilsson (2009) finds that the relationship between health and educational attainment varies by socioeconomic status. Higher-class backgrounds seem to protect children from potentially negative health effects. In terms of mental health, there is evidence that depression, attention deficit symptoms, delinquency, and substance use decrease educational attainment and test scores (Fletcher \& Lehrer, 2009; Fletcher \& Wolfe, 2008; McLeod, Uemura, \& Rohrman, 2012).

These investigations, however, are generally limited to early academic achievement. Extending the window to examine effects on college completion, Nilsson (2008) finds that male children conceived by young mothers after Sweden restricted youth access to alcohol were more likely to complete higher education. Furthermore, the robust evidence that health improves a variety of other educational outcomes suggests those effects are likely to extend to college completion as well. Because mental and physical health are unequally distributed by socioeconomic status (Wilkinson, 1997; Adler, Boyce, Chesney, Folkman, \& Syme, 1993) and because class advantage protects individuals from potentially negative academic effects (Nilsson, 2009), health inequalities represent another mechanism for transmitting inequality.

\subsection{Meritocratic Explanations}

Finally, meritocratic arguments, including ability and intelligence, offer relatively common—if sometimes conservative-explanations for unequal college completion. According to Sewell and Shah (1977), for example, intelligence is more important than socioeconomic status for college graduation because class sorting has already occurred by the time students enroll. The classic functionalist perspective (Davis \& Moore, 1945) suggests schools, including colleges, sort individuals into the position in society most appropriate for their ability (e.g., Sorokin, 1959). In this scenario, students must fail because they do not try hard enough or cannot do the work. In short, these explanations suggest individuals fail to complete college because they are unable to meet the academic standards.

When used to account for unequal college completion rates, however, there are several limitations of the ability argument. We know, for example, that the degree of intergenerational transmission of educational attainment varies across countries (Branigan, McCallum, \& Freese, 2013) and genes only account for about $2 \%$ of the variation in educational attainment (Rietveld et al., 2013). Hereditary transmission of core traits or ability, however, could not be expected to vary according to national boundaries (Hertz et al., 2007). Furthermore, even if genes matter for educational attainment, gene-environment interaction effects suggest that the effects of specific genes depend on social environment (Shanahan, Vaisey, Erickson, \& Smolen, 2008). Thus, even genes matter for college completion, their effects may be moderated by social background.

A further limitation of meritocratic arguments is their reliance on intelligence, which is not simple, constant, or inherent (Gardner, 1983, 1993). Certain forms of intelligence (e.g., logical-mathematical and linguistic) are more valuable than others in an academic context and intelligence changes with time and experience (Flynn, 2007). In addition, because student contributions are filtered through faculty views and cultural backgrounds, 
they are likely to receive different responses by class. In fact, research suggests grades depend on faculty perception and social labeling (e.g., Rist, 1977). Beyond grades, college students from high socioeconomic backgrounds are more likely to meet with professors at their home and spend more time in student clubs (Walpole, 2003). Thus, although all college students were smart and able enough to gain entry to college, that intelligence does not yield equal success.

Perhaps most importantly, meritocratic explanations overlook unequal academic preparation. Drastic inequality between schools generates widely different levels of academic preparation (Condron \& Roscigno, 2003; Kozol, 1991). Academic preparation is critical for student persistence. In fact, rather than interpreting low grades as an indication to study more, students tend to interpret poor performance as inadequate academic preparation (Stinebrickner \& Stinebrickner, 2012). In a recent study by Stinebrickner and Stinebrickner (2013) illustrates the central role of grades and perceived academic preparation for dropout rates; they find that student grades (what students learn about their academic performance) account for $45 \%$ of dropout occurring in the first two years of college and $36 \%$ of dropout in the first three years. Coupled with highly unequal academic preparation, which is virtually ensured by the highly decentralized U.S. education system, variation in grades received in the first few years of college are likely to generate unequal dropout rates by social background.

As suggested by the review above, the classic explanations for unequal college access and completion account for substantial variation in completion by socioeconomic standing. The role of assets, however, remains underappreciated. Assets are critically important to inequality (Oliver \& Shapiro, 1995; Conley, 1999), given their relationship to power and their multi-generational implications. Possibly since Conley (1999, 2001), the contribution of assets to educational inequality has become more apparent and warrants further attention. The remainder of our discussion focuses on this comparatively new explanation for differences in children's educational attainment.

\section{The Transformation of a Legacy of Wealth Inequality into Educational Advantage}

Research suggests that assets may be a particularly important resource for creating educational advantage (Conley, 1999; Oliver \& Shapiro, 1995; Shapiro, 2004; Sherraden, 1991). From this perspective, educational advantage can be thought of as the amount of power an individual has to participate in, influence, control, and hold accountable educational institutions due to inequities in assets holdings. Educational advantages lead to greater success in school. Further, greater success in school translates into increased likelihood of later economic success (Wilson, 1987), including higher income and earnings (King \& Bannon, 2002), more stable employment (Topel, 1993), greater likelihood of marriage (Thornton, Axinn, \& Teachman, 1995), and higher wealth (Oliver \& Shapiro, 1995; Shapiro, 2004).

According to Oliver and Shapiro (1995), high unmet need (the portion of college expenses not covered by the expected family contribution and student aid) is largely the result of low asset accumulation by poor and minority families. In this sense, more assets mean more control over the education system and more control over the education system means more assets. Poor children enter the educational system with few assets. In contrast to wealthy children, then, poor children enter the educational system without the power to make the system work in ways that advantage them.

\section{Transforming Asset Advantages in Higher Education into Right}

For people to achieve their potential, institutions around them must augment their use of effort and abilitywhat Elliott and Sherraden (2013) call institutional facilitation. Institutional facilitation is the process by which institutional efficacy (a person's perception of the extent to which institutions facilitate achievement of her goals) promotes healthy self-efficacy beliefs (a positive view of one's ability to accomplish goals) and the development of positive future identities (e.g., college-bound) (Elliott \& Sherraden, 2013). Institutional facilitation is built on the realization that what separates humans from other mammals is their ability to build tools that augment their innate ability, allowing them to perform at much higher levels than they could otherwise. We no longer live in a state of nature where being bigger, faster, stronger, or smarter matters because we also have access to the tools humans have created. Tools like the computer are able to amplify people's performance in doing math problems, for example, to such a degree that when people do not have access to the same tools they are undeniably at a disadvantage. And, unlike tools used in earlier stages of civilization, today's tools can work nearly invisibly, 
such that it appears that effort and ability alone are responsible for the outcomes realized.

In the next section, we explain how assets help to maintain the educational advantage of middle- and higherincome families by giving them power to determine role expectations. But first we explain role expectations.

\subsection{What Are Role Expectations?}

Role expectations, established by those with superior bargaining power connected by a like desire to receive a disproportionate amount of institutional resources (i.e., distributional advantage), compel others to choose strategies that help the group to maintain a distributional advantage (see Elliott \& Sherraden, 2013; Knight, 1992). Essentially, they induce others to make choices that are not in their own best interests while pretending that these decisions are made freely. This sounds, perhaps, Machiavellian or fanciful, but in the U.S. economy today, it looks natural. The American dream (effort plus ability equals desired outcomes) has been an effective frame for the wealthy to compel the poor to choose strategies that benefit the wealthy. They have been able to do this, in large part, because Americans almost uniformly want to believe that effort and ability are the reason for success and failure. It also should be no surprise that the wealthy overtly continue to emphasize rules that stress effort and ability, while ignoring other factors that play a crucial role in determining success. Through this lens, then, we can better understand why there is so little resistance to this American dream narrative from the poor and minorities.

\subsection{The Power of Assets}

We suggest that in a capitalist society, a key way that a group gains superior bargaining power, in order to gain the leverage through which to establish these important expectations, is through asset accumulation. Institutions (formal and informal) govern the bargaining situation (e.g., negotiation over where educational resources should be spent) and provide sanctions when expectations are violated (Knight, 1992; North, 1990). Because people with assets have power over educational institutions, when needed, they also have the upper hand in changing social expectations (i.e., informal institutions) into rights (i.e., formal institutions) that are enforced by government sanctions in times of heavy competition. In periods of low competition, social sanctions are enough. However, in periods of high competition, social sanctions may not be enough to maintain educational advantages.

For instance, when the college market was opened up to all Americans, the social expectation that college was just for the wealthy was overridden, in part, by the need for a more skilled work force. After World War II, demand for more skilled workers was growing faster than the supply; therefore, the cost for skilled workers sky rocketed (Archibald \& Feldman, 2011). This created an incentive for the owners of capital to increase access to post-secondary education. As a college degree increasingly became the arbiter to power, status, and financial well-being in America, the economy was changing so that more people, including women and minorities, were competing for a college degree in order to be able to earn a good wage.

As a result of the growing competition for college degrees, the wealthy needed to change the distributional consequences of financial aid to maintain their superior bargaining power, particularly when it came to selective universities. We focus on selective universities because the wealthy had two competing interests, one to have more skilled laborers (so it was important to drive down wages of non-skilled jobs and create expectations of having to attend college) but also to maintain advantage when it came to positions of power, status, and financial well-being (so, for example, raising costs of college at selective universities and, at the same time, creating financial aid rules that favored them, such as the shift to merit-based over need-based aid).

It should be clear that we are not suggesting that the shift in financial aid has occurred as part of an organized plan with a puppet master at the controls. The absence of a nefarious scheme, however, does not make the results any less damaging. Instead, we suggest that this shift has been perpetrated by strategic actors leveraging their wealth and bargaining power to act in ways that maximize their own goals. And, once this system is established, it has profound ramifications even for those not fully aware of how it operates. A problem with a system that promotes strategic actors acting in their own self-interest is that the poor and minorities do not start off with equal bargaining power. They cannot, then, influence the rules by which the "game" is played, even though they are then expected to compete in that same arena. So, when the poor and minorities, through the American dream, are expected to use effort and ability to compete at the financial aid table with their wealthy counterparts, they are playing by rules that favor the wealthy in the first place. Therefore, it should be no surprise that we see patterns of enrollment and completion from one generation to the next indicating that lower income and minority 
students lag behind their wealthy, white counterparts.

First, this is because through a legacy of class and racial inequality in America, the wealthy have the power, through financial assets, to control how resources are distributed. Therefore, for example, they were able to change the student loan program (e.g., allowing higher-income families to be eligible for a student loan), originally designed to distribute resources primarily to the poor as a way of improving their access to college, to benefit them (e.g., Kinzie, Palmer, Hayek, Hossler, Jacob, \& Cummings, 2004). Second, through a legacy of class and racial inequality in America, the wealthy come to the financial aid table with superior bargaining power. This superior bargaining power is derived, at least in part, from the fact that they have more assets, so can pay more for the college of their choice and, coming from better resourced schools and home environments, are better prepared for college. In this way, a normative expectation like the American dream, when applied to a group in the context of inequality, can form a negative role expectation for the group or a role expectation that leads the group to make decisions that benefit the group with superior bargaining power.

Therefore, the shift in financial aid toward privatization and merit might have led to very different results if all strategic actors started off with the same level of assets—if the playing field was level. But because a group in society was uniquely positioned to control the development of role expectations, they were able to benefit more from the financial aid system and even produce a system that provides them with an ever-growing share of grants, scholarships, and tax incentives, in addition to access to student loans.

\subsection{Leveraging Wealth to Create an Advantage at the Financial Aid Table}

Prior to the Servicemen's Readjustment Act of 1944, commonly known as the GI Bill, college students were primarily male, white, and wealthy (Rudolph, 1990). Given this, there was very little competition from outside groups for selection into higher education; particularly selection into the most selective universities. However, a growing need for skilled workers created competing desires among the owners of capital—desire to maintain control over higher education and a desire to have a greater number of skilled workers. These desires did not develop in a vacuum; instead, they developed as a result of ongoing economic and political changes, advancements in technology as well as social changes that led to increasing rights for women and minorities in the 1960s. In response, the federal government enacted the Higher Education Act of 1965. An express purpose of the Act was to create greater access to college among lower- and middle-income families through the creation of scholarships, low-interest loans, and work study programs.

Despite what would come, during the 1960s and 1970s the goal of financial aid was to keep tuition prices down and increase financial aid to the poor and minorities, those least represented in colleges and universities at the time (and still today). For example, in 1900, there were 3,880 black students in colleges and professional schools and fewer than 400 graduates of college and professional programs. These new graduates were added to the existing pool of about 3,000 other graduates in a total black population of nearly 10 million (Goodchild \& Wechsler, 1997). Financial aid policy at the time attempted to address the unequal starting points of these different populations and to mitigate some of the effects of disparate role expectations on individual students. During this period, need-based aid was the dominant form of financial aid. Need-based aid is determined solely on the assets and income (i.e., financial need) of the prospective student and her family. Factors such as test scores had no bearing on the aid decision.

Changes in the Higher Education Act of 1965 that occurred in 1972 opened up the door for the privatization as well the marketization of higher education (Mendoza, 2012). In 1972, the Higher Education Act of 1965 was amended to give aid directly to students instead of to institutions. This shift of resources set the stage for cost shifts, as individuals and families have been increasingly expected to take on the lion's share of the burden of paying for college and colleges have been thrust into competition for students' financial aid dollars. Both of these policy changes favored the wealthy. The wealthy were in a better position to take on increased responsibility for paying for college. This helped to make wealthy students more attractive to universities, particularly the more costly, selective universities. In this sense, it was not that wealthy students and their families acted to create laws that favored them; but instead, because of their wealth advantage they were able to benefit more from the changes that occurred. In a society where effort and ability are seen as the determining factors for success, shifts toward privatization sound just. However, low-income and minority students are disadvantaged in a privatized context because they do not have resources that allow them to compete effectively with wealthy students. 
While in the 1960s and 1970s low-income students and their families could rely more heavily on grants to make up for a lack of income and savings, the shift from need-based aid toward merit-based aid starting in the 1980s led to a financial aid program that largely subsidizes middle- to upper-income, white students to attend college (Baum \& Schwartz, 1988; Woo \& Choy, 2011). Woo and Choy (2011) find that the proportion of undergraduates receiving merit aid rose from $6 \%$ in 1995/96 to 14\% in 2007/2008. In the case of merit-based aid, of which scholarships are the most common form, a student with little financial need (i.e., higher assets and income) is just as entitled to aid as are students with high levels of financial need (i.e., lower assets and income). Test scores are often the key factor for determining eligibility.

Far from serving to equalize college prospects, research suggests that merit-based aid is awarded disproportionately to students from higher-income families (Cornwell \& Mustard, 2002; Selingo, 2003; Woo \& Choy, 2011) whose superior resource base equips them to perform well in the competition for merit-based aid. Not surprisingly, then, merit-based aid has done little to improve college enrollment rates among low-income and minority students (Marin, 2002). In this way, it might be said the shift toward merit-based aid is another way that resources are being diverted from lower-income students to higher-income students. Additionally, given the effects of income and asset poverty on educational achievement (see Elliott, 2013a, for evidence of economic instability effects on educational outcomes), the shift toward merit aid may exacerbate the divides in attainment by social class. This may also help to establish a set of role expectations that augment higher-income students' ability to attend college while constraining lower-income students' ability to attend college even when highly qualified $^{2}$.

Disadvantageous role expectations do not stem from overt biases but from invisibly seating class and racial legacies at the financial aid table. Here, again, the allure of the rhetorical American dream is so important. Belief that individual effort and ability are the driving forces influencing educational outcomes works to obscure the powerful role of relative institutional advantages.

The distorting effects of these role expectations are not only seen at the point of deciding whether or not to attend college at all, however. Additionally, many high-achieving low-income students fail to apply to selective institutions even though they would receive more financial aid and have to pay less (Hoxby \& Avery, 2012), while likely realizing superior educational outcomes than if they attended less selective colleges and universities. The pattern of behaving in ways that would not be considered normative is in accordance with acting in line with disadvantageous role expectations. These role expectations, which communicate to all that low-income and minority students are better off at low-cost colleges even when they are more than qualified for more selective colleges with better graduation rates and superior post-college outcomes, are disadvantageous because of the advantages that attending a selective college bestows upon its students.

The type of institution a student attends-e.g., two- or four-year, private or public, selective or non-selective, and size-has important implications for the likelihood of graduating (Carnevale \& Strohl, 2010). Two-year colleges have lower retention rates than four-year schools, even after accounting for differences in the types of students (Tinto, 1987). Because those who attend two-year schools tend to come from families with fewer advantages, these retention differences exacerbate inequality. Similarly, private and more selective postsecondary institutions have higher retention rates on average. As Davies and Guppy (1997) point out, student socioeconomic status is related to the likelihood of entering a selective college, and even choosing a lucrative major within a selective college. Low-income students attending private or selective schools are also more likely to encounter socioeconomically advantaged peers who can positively influence graduation, catalyze formation of social networks, and help low-income students bridge gaps of cultural capital. This all translates into students in more selective four-year colleges being set on a path to enter high-paying careers (Carnevale \& Strohl, 2010). Instead, students in less-selective four-year colleges are being put on a path to fill positions in "K-12 teaching, health care technician jobs, and state and local public administration” (Carnevale \& Strohl, 2010: p. 79) which have less earning potential and lower social status. Again, the question is not whether these are superior paths to those that would have been available to these students without college degrees but, instead, whether education can truly be said to serve an equalizing role in the U.S. economy with these disparate outcomes.

With the shift toward privatization of the financial aid system and the failure of income, tax subsidies, and grants to fill the financial aid gap, student loans have become the most commonly used tool for building students' and families' capacities for financing college. Fry (2012) finds that the proportion of undergraduate students who took out federal loans increased from 23\% in 2001-2002 to 35\% in 2011-2012 (College Board, 2012). Not

\footnotetext{
${ }^{2}$ See the discussion about role expectations in chapter four of AEDI (2013).
} 
only are more students borrowing, but borrowing students are also borrowing more. According to Fry (2012), the average outstanding student loan debt in 2007 was $\$ 23,349$, and it rose to $\$ 26,683$ by 2010. Further, total borrowing for college hit $\$ 113.4$ billion for the 2011-2012 school year, up 24\% from five years earlier (College Board, 2012). As a result, households are faced with ever-growing debt. In the 2011-2012 school year, about 37\% (\$70.8 billion) of all undergraduate financial aid received came from federal loans (College Board, 2012). The next highest source of aid was federal Pell Grants at $19 \%$ and institutional grants at $18 \%$.

The trend toward student loans making up a growing proportion of financial aid packages is in large part the result of changes in financial aid policies meant to create greater access to college for lower-income students. This problem is caused by high college costs, stagnant wages, and the shift toward privatization. The federal government has increased access to loans largely through programs such as the federal Parent PLUS Loan and Stafford subsidized and unsubsidized loan programs. For example, the Middle Income Student Assistance Act (1978) brought college loans to the middle class by removing the income limit for participation in federal aid programs (Hansen, 1983).

The 1992 amendments to the Higher Education Act made unsubsidized loans available, and the Omnibus Budget Reconciliation Act (1993) included provisions for the Federal Direct Loan Program. More recently, Congress raised the ceiling on the amount of individual federal Stafford loans students can borrow through the Ensuring Continued Access to Student Loans Act (2008). The Health Care and Education Reconciliation Act (2010) routed all federal loans through the Direct Loan program, making it easier for students and parents to borrow directly from the U.S. Department of Education.

However, the enthusiasm policymakers have shown for student borrowing as the solution to the college affordability gap has not necessarily translated to benefits for lower-income students, who are more likely to be averse to taking out high-dollar student loans to pay for college (Cunningham \& Santiago, 2008). Especially for these students, the prospect of signing for thousands of dollars in debt may lead to decisions to go to less selective two-year colleges, to work while attending school, and/or to delay enrollment, all practices potentially associated with compromised college graduation rates (Carnevale \& Strohl, 2010).

Somewhat ironically, as is the case with disadvantageous role expectations which compel people to make decisions that benefit the group who created them, Carnevale and Strohl (2010) report that students who attend a selective college pay smaller shares of the costs of their education relative to students in two-year and less-selective four-year colleges. They state, "Students in the wealthiest 10 percent of institutions pay 20 cents for each dollar spent on them. Students in the poorest 10 percent of colleges pay 78 cents for each dollar spent on them" (p. 79).

Federal policies that liberalized student loans have also created an environment where universities can charge wealthy students the full list price. This is done while not pricing out lower income students by offering them financial aid packages that charge them less than the list price. This has allowed universities to charge each student the maximum amount they can afford to pay (Geiger \& Heller, 2011) now or in the future, thus maximizing universities' gain from financial aid, per student. However, it stands to reason that schools would have a preference for wealthier students that they can charge the full list price to and a limit on the number of lower income students they can admit.

\section{Reversing a Legacy of Wealth Inequality in Higher Education}

In order to eliminate education advantage, the distributional consequences of the current financial aid rules (e.g., merit aid) must be changed in the case of low-income and minority students. These rules can be changed by changing either the distributional consequences of the financial aid system or the relative bargaining power of low-income and minority students (see Knight, 1992). This change is mostly likely to come through government intervention in the free market of education-redistribution in some form. In the current higher education landscape, which features rapidly rising costs and offers debt in the form of student loans as the primary means for disadvantaged students to overcome cost barriers, responsibility for challenging disadvantageous role expectations primarily lies with low-income or minority parents, philanthropic organizations, or other benevolent actors. However, low-income parents are at a disadvantage for providing the kind of financial resources needed to counteract disadvantageous role expectations. Philanthropic groups tend to focus on ad hoc solutions-providing needed material goods or services to a particular low-income child—without addressing the structural factors that led to the child lacking such necessities in the first place. 


\subsection{A Policy Vehicle for Allocating Assets to Low- and Moderate-Income Students}

Children's Savings Accounts (CSAs) are one type of government intervention in the free market of education that may offer a systemic answer to disadvantageous role expectations, empowering more low-income and minority students to apply for college, and to more selective colleges, and preparing them for success once there. CSAs have been proposed as a promising strategy that promotes low-income children's savings, asset accumulation, and development of financial, social, and human capital (Boshara, 2003; Goldberg, 2005). CSAs are savings vehicles that often incorporate specific incentives and explicit structures to encourage savings and facilitate asset accumulation by disadvantaged youth and families who otherwise may not have equitable access to financial institutions. CSAs usually allow deposits from children, their parents and other relatives, as well as third parties. These investments can be leveraged with an initial deposit and/or matching funds adding public or philanthropic funds to families' savings, usually on a ratio ranging from 1:1 - 5:1. This policy extends meaningful incentives for saving and support for building the assets of low-income savers, which are already available to higher-income households through tax benefits.

CSA programs may place role expectations back in line with students' best interests by ensuring that college appears attainable to children throughout their time in school (AEDI, 2013). CSA programs may also give students a sense of community support for their education, through community-organized, third party contributions to CSA accounts. These kinds of contributions ensure that each child in a community forms a college-bound identity rooted in a durable community identity around college attendance and success. These new relationships and this altered context can reset the messages children may hear elsewhere about the likelihood of college in their own futures, thus supporting identities that feature high educational expectations.

\section{Conclusion}

We have discussed multiple explanations for unequal access to and completion of college in the U.S., with a particular focus on the role of assets. With a less common explanation for educational inequality, assets play a central role in the likelihood of entering and completing college in the U.S. The long U.S. legacy of unequal access to college degrees and assets are not separate issues, but-partly by design of those with economic and political power-represent two sides of the same coin. Assets beget educational advantage and educational advantage begets assets, reproducing inequality across generations.

Rising inequality and tuition costs create an urgent need for changes in the U.S. system of paying for college. College savings accounts offer a potential strategy to increase assets among children from disadvantaged backgrounds. As evidence shows, savings can not only increase college access and completion rates, but also encourage a college bound identity, academic preparation for college, and greater financial health in later life. The U.S. must shift away from a debt-based system of paying for college or risk sentencing graduates to a life of student loan payments. College savings accounts offer a policy change that can begin to level the playing field.

\section{Acknowledgements}

This work was supported by the Assets and Education Initiative in the School of Social Welfare at the University of Kansas.

\section{References}

Acs, G., Loprest, P., \& Nichols, A. (2009). Risk and Recovery: Understanding the Changing Risks to Family Incomes Low-Income Working Families. Washington DC: The Urban Institute.

Assets and Education Initiative (2013). Building Expectations, Delivering Results: Asset-Based Financial Aid and the Future of Higher Education. In W. Elliott (Ed.), Biannual Report on the Assets and Education Field. Lawrence, KS: Assets and Education Initiative (AEDI).

Adler, N. E., Boyce, W. T., Chesney, M. A., Folkman, S., \& Syme, S. L. (1993). Socioeconomic Inequalities in Health: No Easy Solution. Journal of the American Medical Association, 269, 3140-3145. http://dx.doi.org/10.1001/jama.1993.03500240084031

Almond, D. (2006). Is the 1918 Influenza Pandemic over? Long-Term Effects of in Utero Influenza Exposure in the Post-1940 U.S. Population. Journal of Political Economy, 114, 672-712. http://dx.doi.org/10.1086/507154

Almond, D., Edlund, L., \& Palme, M. (2009). Chernobyl’s Subclinical Legacy: Prenatal Exposure to Radioactive Fallout and 
School Outcomes in Sweden. Quarterly Journal of Economics, 124, 1729-1772.

http://dx.doi.org/10.1162/qjec.2009.124.4.1729

Almond, D., \& Mazumder, B. (2005). The 1918 Influenza Pandemic and Subsequent Health Outcomes: An Analysis of SIPP data. The American Economic Review, 95, 258-262. http://dx.doi.org/10.1257/000282805774669943

Archibald, R. B., \& Feldman, D. H. (2011) Why Does College Cost So Much? New York: Oxford University Press.

Attewell, P., \& Lavin, D. E. (2007). Passing the Torch: Does Higher Education for the Disadvantaged Pay off across the Generations? New York: Russell Sage Foundation.

Autor, D. H. (2014). Skills, Education, and the Rise of Earnings Inequality among the “Other 99 Percent.” Science, 344, 843-851. http://dx.doi.org/10.1126/science.1251868

Baum, S., \& Schwartz, S. (1988). Merit Aid to College Students. Economics of Education Review, 7, 127-134. http://dx.doi.org/10.1016/0272-7757(88)90077-5

Behrman, J. R., \& Rosenzweig, M. R. (2004). Returns to Birthweight. The Review of Economics and Statistics, 86, 586-601. http://dx.doi.org/10.1162/003465304323031139

Belman, D., \& Heywood, J. (1991). Sheepskin Effects in the Return to Education. Review of Economics and Statistics, 73, 720-724. http://dx.doi.org/10.2307/2109413

Black, S. E., Devereux, P. J., \& Salvanes, K. G. (2007). From the Cradle to the Labor Market? The Effect of Birth Weight on Adult Outcomes. Quarterly Journal of Economics, 122, 409-439. http://dx.doi.org/10.1162/qjec.122.1.409

Blau, P. M., \& Duncan, O. D. (1967). The American Occupational Structure. New York: John Wiley and Sons.

Boshara, R. (2003). Federal Policy and Asset Building. Social Development Issues, 25, 130-141.

Bourdieu, P. (1977). Cultural Reproduction and Social Reproduction. In J. Karabel, \& A. H. Halsey (Eds.), Power and Ideology in Education (pp. 487-511). New York: Oxford University Press.

Bowen, W. G., Chingos, M. M., \& McPherson, M. S. (2009). Crossing the Finish Line: Completing College at America's Public Universities. Princeton, NJ: Princeton University Press.

Branigan, A. R., McCallum, K. J., \& Freese, J. (2013).Variation in the Heritability of Educational Attainment: An International Meta-Analysis. Social Forces, 92, 109-140. http://dx.doi.org/10.1093/sf/sot076

Card, D., \& Krueger, A. (1996). School Resources and Student Outcomes: An Overview of the Literature and New Evidence from North and South Carolina. Journal of Economic Perspectives, 10, 31-50. http://dx.doi.org/10.1257/jep.10.4.31

Carnevale, A. P., \& Strohl, J. (2010). How Increasing College Access Is Increasing Inequality and What to Do about It. In R. Kahlenberg (Ed.), Rewarding Strivers: Helping Low-Income Students Succeed in College (pp. 1-231). New York: Century Foundation Books.

Carnevale, A. P., Smith, N., Stone III, J. R., Kotamraju, P., Steuernagel, B., \& Green, K. A. (2011). Career Clusters: Forecasting Demand for High School through College Jobs. Washington DC: Georgetown University, Center on Education and the Workforce.

Collier, P., \& Morgan, D. (2008). Is That Paper Really Due Today? Differences in First Generation and Traditional College Students' Understandings of Faculty Expectations. Higher Education, 55, 425-446. http://dx.doi.org/10.1007/s10734-007-9065-5

Condron, D. J., \& Roscigno, V. J. (2003). Disparities within: Unequal Spending and Achievement in an Urban School District. Sociology of Education, 76, 18-36. http://dx.doi.org/10.2307/3090259

Conley, D. (1999). Being Black, Living in the Red: Race, Wealth and Social Policy in America. Berkeley, CA: University of California Press.

Conley, D. (2001). Capital for college: Parental Assets and Postsecondary Schooling. Sociology of Education, 74, 59-72. http://dx.doi.org/10.2307/2673145

Conley, D., Strully, K. W., \& Bennett, N. G. (2003). The Starting Gate: Birth Weight and Life Chances. Berkeley, CA: University of California Press.

Cookson, P. W., \& Persell, C. H. (1985). Preparing for Power: America's Elite Boarding Schools. New York: Basic Books.

Cornwell, C. M., \& Mustard, D. M. (2002). Race and the Effects of Georgia’s HOPE Scholarship. In D. E. Heller, \& P. Marin (Eds.), Who Should We Help? The Negative Social Consequences of Merit Scholarships (pp. 57-72). Cambridge, MA: The Civil Rights Project, Harvard University.

Cunningham, A. F., \& Santiago, D. A. (2008). Student Aversion to Borrowing: Who Borrows and Who Doesn’t. Washington DC: Institute for Higher Education Policy and Excelencia in Education.

Davies, S., \& Guppy, N. (1997). Field of Study, College Selectivity and Student Inequalities in Higher Education. Social Forces, 75, 1417-1438. http://dx.doi.org/10.1093/sf/75.4.1417

Davis, K., \& Moore, W. E. (1945). Some Principles of Stratification. American Sociological Review, 10, $242-249$. http://dx.doi.org/10.2307/2085643 
DiMaggio, P. (1982). Cultural Capital and School Success: The Impact of Status Culture Participation on the Grades of U.S. high School Students. American Sociological Review, 47, 189-201. http://dx.doi.org/10.2307/2094962

Eckles, J. E., \& Stradley, E. G. (2012). A Social Network Analysis of Student Retention Using Archival Data. Social Psychology of Education, 15, 165-180. http://dx.doi.org/10.1007/s11218-011-9173-z

Eide, E. R., \& Showalter, M. H. (2011). Estimating the Relation between Health and Education: What Do We Know and What Do We Need to Know? Economics of Education Review, 30, 778-791. http://dx.doi.org/10.1016/j.econedurev.2011.03.009

Elliott, W. (2013a). The Effects of Economic Instability on Children's Educational Outcomes. Children and Youth Services Review, 35, 461-471. http://dx.doi.org/10.1016/j.childyouth.2012.12.017

Elliott, W. (2013b). Small-Dollar Children’s Savings Accounts and Children’s College Outcomes. Children and Youth Services Review, 35, 572-585. http://dx.doi.org/10.1016/j.childyouth.2012.12.015

Elliott, W., \& Sherraden, M. S. (2013). Institutional Facilitation and CSA Effects (Chapter 2). In W. Elliott (Ed.), Building Expectations, Delivering Results: Asset-Based Financial Aid and the Future of Higher Education. Biannual Report on the Assets and Education Field. Lawrence, KS: Assets and Education Initiative.

Elliott, W., Song, H. A., \& Nam, I. (2013). Small-Dollar Children’s Savings Accounts and Children’s College Outcomes by Income Level. Children and Youth Services Review, 35, 560-571. http://dx.doi.org/10.1016/j.childyouth.2012.12.003

Ermisch, J., Jäntti, M., \& Smeeding, T. (2012). From Parents to Children: The Intergenerational Transmission of Advantage. New York: Russell Sage Foundation.

Fletcher, J., \& Wolfe, B. L. (2008). Child Mental Health and Human Capital Accumulation: The Case of ADHD Revisited. Journal of Health Economics, 27, 794-800. http://dx.doi.org/10.1016/j.jhealeco.2007.10.010

Fletcher, J. M., \& Lehrer, S. F. (2009). The Effects of Adolescent Health on Educational Outcomes: Causal Evidence Using Genetic Lotteries between Siblings. Forum for Health Economics \& Policy, 12, Article 8.

http://dx.doi.org/10.2202/1558-9544.1180

Flynn, J. R. (2007). What Is Intelligence? New York: Cambridge University Press. http://dx.doi.org/10.1017/CBO9780511605253

Friedline, T., Elliott, W., \& Nam, I. (2013). Small-Dollar Children’s Savings Accounts and Children’s College Outcomes by Race. Children and Youth Services Review, 35, 548-559. http://dx.doi.org/10.1016/j.childyouth.2012.12.007

Fry, R. (2012). A Record One-in-Five Households Now Owe Student Loan Debt. Washington DC: Pew Research Center. www.pewsocialtrends.org/2012/09/26/a-record-one-in-five-households-now-owe-student-loan-debt/

Gardner, H. (1983). Frames of Mind: The Theory of Multiple Intelligences. New York: Basic Books.

Gardner, H. (1993). Multiple Intelligences: The Theory in Practice. New York: Basic Books.

Geiger, R. L., \& Heller, D. E. (2011). Financial Trends in Higher Education: The United States. Center for the Study of Higher Education. http://www.ed.psu.edu/educ/cshe/working-papers/WP\%236

Goldberg, F. (2005). The Universal Piggy Bank: Designing and Implementing a System of Universal Accounts for Children. In M. Sherraden (Ed.), Inclusion in the American Dream: Assets, Poverty and Public Policy. New York: Oxford University Press.

Goodchild, L. F., \& Wechsler, H. S. (1997). The History of Higher Education (2nd ed.). Needham Heights, MA: Pearson Learning Solutions.

Greenwald, R. (2012). Think of First-Generation Students as Pioneers, Not Problems. The Chronicle of Higher Education. http://chronicle.com/article/Think-of-First-Generation/135710/

Hamilton, L. (2013). More Is More or More Is Less? Parental Financial Investments during College. American Sociological Review, 78, 70-95. http://dx.doi.org/10.1177/0003122412472680

Haskins, R. (2008). Education and Economic Mobility. In J. B. Isaacs, I. V. Sawhill, \& R. Haskins (Eds.), Getting ahead or Losing Ground: Economic Mobility in America. Washington DC: The Brookings Institution.

Hertz, T., Jayasundera, T., Piraino, P., Selcuk, S., Smith, N., \& Verashchagina, A. (2007). The Inheritance of Educational Inequality: Intergenerational Comparison and Fifty-Year Trends. The B.E. Journal of Economic Analysis \& Policy, 7, Article 10 .

Hout, M. (1984). Status, Autonomy and Training in Occupational Mobility. American Journal of Sociology, 89, $379-409$. http://dx.doi.org/10.1086/228020

Hout, M. (1988). More Universalism, Less Structural Mobility: The American Occupational Structure in the 1980s. American Journal of Sociology, 93, 1358-1400. http://dx.doi.org/10.1086/228904

Hoxby, C. M., \& Avery, C. (2012). The Missing “One-Offs”: The Hidden Supply of High-Achieving, Low-Income Students. National Bureau of Economic Research Working Paper No. 18586. Cambridge, MA: National Bureau of Economic Re- 
search.

Jäntti, M., Bratsberg, B., Roed, K., Raaum, O., Naylor, R., Osterbacka, E., \& Eriksson, T. (2006). American Exceptionalism in a New Light: A Comparison of Intergenerational Earnings Mobility in the Nordic Countries, The United Kingdom and The United States. Institute for the Study of Labor (IZA) Discussion Paper No. 1938.

Johnson, H. B. (2006). The American Dream and the Power of Wealth: Choosing Schools and Inheriting Inequality in the Land of Opportunity. New York: Routledge.

Kalleberg, A. L. (2011). Good Jobs, Bad Jobs: The Rise of Polarized and Precarious Employment Systems in the United States, 1970s to 2000s. New York: Russell Sage Foundation.

Khan, S. (2011). Privilege: The Making of an Adolescent Elite at St. Paul's School. Princeton, NJ: Princeton University Press.

Kim, Y., \& Sherraden, M. (2011). Do Parental Assets Matter for Children's Educational Attainment? Evidence from Mediation Tests. Children and Youth Services Review, 33, 969-979. http://dx.doi.org/10.1016/j.childyouth.2011.01.003

King, T., \& Bannon, E. (2002). At What Costs? The Price That Working Students Pay for a College Education. www.pirg.org/highered/atwhatcost4_16_02.pdf

Kinzie, J., Palmer, M., Hayek, J., Hossler, D., Jacob, S., \& Cummings, H. (2004). Fifty Years of College Choice: Social, Political and Institutional Influences on the Decision-Making Process (Vol. 5). Indianapolis, IN: Lumina Foundation for Education.

Knight, J. (1992). Institutions and Social Conflict. Cambridge, NY: Cambridge University Press. http://dx.doi.org/10.1017/CBO9780511528170

Lareau, A. (2002). Invisible Inequality: Social Class and Childrearing in Black Families and White Families. American Sociological Review, 67, 747-776. http://dx.doi.org/10.2307/3088916

Lareau, A. (2003). Unequal Childhoods: Class, Race and Family Life. Berkeley, CA: University of California Press.

Lareau, A. (2011). Unequal Childhoods: Race, Class and Family Life (2nd ed.). Berkeley, CA: University of California Press.

Mare, R. M., \& Tzeng, M. (1989). Father's Ages and the Social Stratification of Sons. American Journal of Sociology, 95, 108-131. http://dx.doi.org/10.1086/229215

Marin, P. (2002). Merit Scholarships and the Outlook for Equal Opportunity in Higher Education. In D. E. Heller, \& P. Marin (Eds.), Who Should We Help? The Negative Social Consequences of Merit Scholarships (pp. 109-114). Cambridge, MA: The Civil Rights Project at Harvard University.

Mayer, S. E. (1997). What Money Can’t Buy: Family Income and Children's Life Chances. Cambridge, MA: Harvard University Press.

McKernan, S., Ratcliffe, C., \& Vinopal, K. (2009). Do Assets Help Families Cope with Adverse Events? Perspectives on Low-Income Working Families, Brief 10. Washington DC: The Urban Institute.

McLeod, J. D., Uemura, R., \& Rohrman, S. (2012). Adolescent Mental Health, Behavior Problems and Academic Achievement. Journal of Health and Social Behavior, 53, 482-497. http://dx.doi.org/10.1177/0022146512462888

Mendoza, P. (2012). The Effect of Debt and Working While Enrolled on Baccalaureate Completion: A Counterfactual Analysis. Journal of Student Financial Aid, 42, 25-59.

Nam, Y., \& Huang, J. (2009). Equal Opportunity for All? Parental Economic Resources and Children's Educational Attainment. Children and Children Services Review, 31, 625-634.

National Center for Educational Statistics (2013). The Condition of Education 2013 (NCES 2013-037). Institutional Retention and Graduation Rates for Undergraduate Students. US Department of Education.

http://nces.ed.gov/fastfacts/display.asp?id=40.

Nilsson, P. (2008). Does a Pint a Day Affect Your Child's Pay? The Effect of Prenatal Alcohol Exposure on Adult Outcomes. Centre for Microdata Methods and Practice Working Paper CWP22/08, The Institute for Fiscal Studies. www.cemmap.ac.uk/wps/cwp2208.pdf.

Nilsson, P. (2009). The Long-Term Effects of Early Childhood Lead Exposure: Evidence from Sharp Changes in Local Air Lead Levels Induced by the Phase-Out of Leaded Gasoline. Manuscript, Uppsala: Uppsala University. www.eea-esem.com/files/ papers/EEA/2010/1722/lead\%20exposure.pdf.

North, D. C. (1990). Institutions, Institutional Change and Economic Performance. Cambridge, NY: Cambridge University Press. http://dx.doi.org/10.1017/CBO9780511808678

Oliver, M. L., \& Shapiro, T. M. (1995). Black Wealth/White Wealth: A New Perspective on Racial Inequality. New York: Routledge.

Oreopoulos, P., Page, M. E., \& Stevens, A. H. (2006). The Intergenerational Effects of Compulsory Schooling. Journal of Labor Economics, 24, 729-760. http://dx.doi.org/10.1086/506484 
Oreopoulos, P., Stabile, M., Roos, L., \& Walld, R. (2008). The Short, Medium and Long Term Effects of Poor Infant Health. Journal of Human Resources, 43, 88-138. http://dx.doi.org/10.1353/jhr.2008.0003

Ostrove, J. M., \& Long, S. M. (2007). Social Class and Belonging: Implications for College Adjustment. The Review of Higher Education, 30, 363-389. http://dx.doi.org/10.1353/rhe.2007.0028

Pew Charitable Trusts (2013). Hard Choices: Navigating the Economic Shock of Unemployment. Washington DC: Pew Charitable Trusts. www.pewstates.org/

Powell, B., \& Steelman, L. C. (1990). Beyond Sibship Size: Sibling Density, Sex Composition and Educational Outcomes. Social Forces, 69, 181-206. http://dx.doi.org/10.1093/sf/69.1.181

Rietveld, C. A., Medland, S. E., Derringer, J. et al. (2013). GWAS of 126,559 Individuals Identifies Genetic Variants Associated with Educational Attainment. Science, 340, 1467-1471. http://dx.doi.org/10.1126/science.1235488

Rist, R. C. (1977). On Understanding the Process of Schooling: Contributions of Labeling Theory. In J. Karabel, \& A. H. Halsey (Eds.), Power and Ideology in Education (pp. 292-305). New York: Oxford University Press.

Royer, H. (2009). Separated at Girth: US Twin Estimates of the Effects of Birth Weight. American Economic Journal: Applied Economics, 1, 49-85.

Rudolph, F. (1990). The American College and University: A History. Athens, GA: University of Georgia Press.

Sacerdote, B. (2001). Peer Effects with Random Assignment: Results for Dartmouth Roommates. The Quarterly Journal of Economics, 116, 681-704. http://dx.doi.org/10.1162/00335530151144131

Selingo, J. (2003). HOPE Wanes for Georgia’s Merit-Based Scholarships. Chronicle of Higher Education, A1.

Sewell, W., \& Shah, V. (1977). Socioeconomic Status, Intelligence and Attainment of Higher Education. Sociology of Education, 40, 1-23. http://dx.doi.org/10.2307/2112184

Shanahan, M. J., Vaisey, S., Erickson, L. D., \& Smolen, A. (2008). Environmental Contingencies and Genetic Propensities: Social Capital, Educational Continuation, and Dopamine Receptor Gene DRD2. American Journal of Sociology, 114, S260S286. http://dx.doi.org/10.1086/592204

Shapiro, T. M. (2004). The Hidden Cost of Being African American: How Wealth Perpetuates Inequalities. New York: Oxford University Press.

Sherraden, M. (1991). Assets and the Poor: A New American Welfare Policy. Armonk, NY: M.E. Sharpe.

Song, H., \& Elliott, W. (2011). The Role of Assets in Improving College Attainment among Hispanic Immigrant Youth in the U.S. Children and Youth Services Review, 33, 2160-2167. http://dx.doi.org/10.1016/j.childyouth.2011.06.023

Sorokin, P. (1959). Social and Cultural Mobility. New York: The Free Press.

Spenner, K., Buchmann, C., \& Landerman, L. R. (2005). The Black-White Achievement Gap in the First College Year: Evidence from a New Longitudinal Case Study. Research in Social Stratification and Mobility, 22, 187-216. http://dx.doi.org/10.1016/S0276-5624(04)22007-8

Steelman, L. C., Powell, B., Werum, R., \& Carter, S. (2002). Reconsidering the Effects of Sibling Configuration: Recent Advances and Challenges. Annual Review of Sociology, 28, 243-269. http://dx.doi.org/10.1146/annurev.soc.28.111301.093304

Stephens, N. M., Fryberg, S. A., Markus, H. R., Johnson, C. S., \& Covarrubias, R. (2012). Unseen Disadvantage: How American Universities' Focus on Independence Undermines the Academic Performance of First-Generation College Students. Journal of Personality and Social Psychology, 102, 1178-1197. http://dx.doi.org/10.1037/a0027143

Stinebrickner, T., \& Stinebrickner, R. (2012). Learning about Academic Ability and the College Drop-Out Decision. Journal of Labor Economics, 30, 707-748. http://dx.doi.org/10.1086/666525

Stinebrickner, T., \& Stinebrickner, R. (2013). Academic Performance and College Dropout: Using Longitudinal Expectations Data to Estimate a Learning Model. NBER Working Paper 18945. www.nber.org/papers/w18945.

Thornton, A., Axinn, W. G., \& Teachman, J. D. (1995). The Influence of School Enrollment and Accumulation on Cohabitation and Marriage in Early Adulthood. American Sociological Review, 60, 762-774. http://dx.doi.org/10.2307/2096321

Tinto, V. (1975). Dropout from Higher Education: A Theoretical Synthesis of Recent Research. Review of Educational Research, 45, 89-125. http://dx.doi.org/10.3102/00346543045001089

Tinto, V. (1987). Leaving College: Rethinking the Causes and Cures for Student Attrition. Chicago, IL: University of Chicago Press.

Torche, F. (2011). Is a College Degree Still the Great Equalizer? Intergenerational Mobility across Levels in the United States. American Journal of Sociology, 117, 763-807. http://dx.doi.org/10.1086/661904

Walpole, M. (2003). Socioeconomic Status and College: How SES Affects College Experiences and Outcomes. The Review of Higher Education, 27, 45-73. http://dx.doi.org/10.1353/rhe.2003.0044

Wells, R. (2008). The Effects of Social and Cultural Capital on Student Persistence: Are Community College More Merito- 
cratic? Community College Review, 36, 25-46. http://dx.doi.org/10.1177/0091552108319604

Wilkinson, R. G. (1997). Socioeconomic Determinants of Health: Health Inequalities: Relative or Absolute Material Standards? British Medical Journal, 314, 591-595. http://dx.doi.org/10.1136/bmj.314.7080.591

Wilson, W. J. (1987). The Truly Disadvantaged: The Inner City, the Underclass and Public Policy. Chicago, IL: University of Chicago Press.

Woo, J. H., \& Choy, S. P. (2011). Merit Aid for Undergraduates: Trends from 1995-1996 to 2007-2008 (NCES 2012-160). US Department of Education, National Center for Education Statistics.

Zhan, M., \& Sherraden, M. (2011). Assets and Liabilities, Educational Expectations and Children's College Degree Attainment. Children and Youth Services Review, 33, 846-854. http://dx.doi.org/10.1016/j.childyouth.2010.12.006 
Scientific Research Publishing (SCIRP) is one of the largest Open Access journal publishers. It is currently publishing more than 200 open access, online, peer-reviewed journals covering a wide range of academic disciplines. SCIRP serves the worldwide academic communities and contributes to the progress and application of science with its publication.

Other selected journals from SCIRP are listed as below. Submit your manuscript to us via either submit@scirp.org or Online Submission Portal.
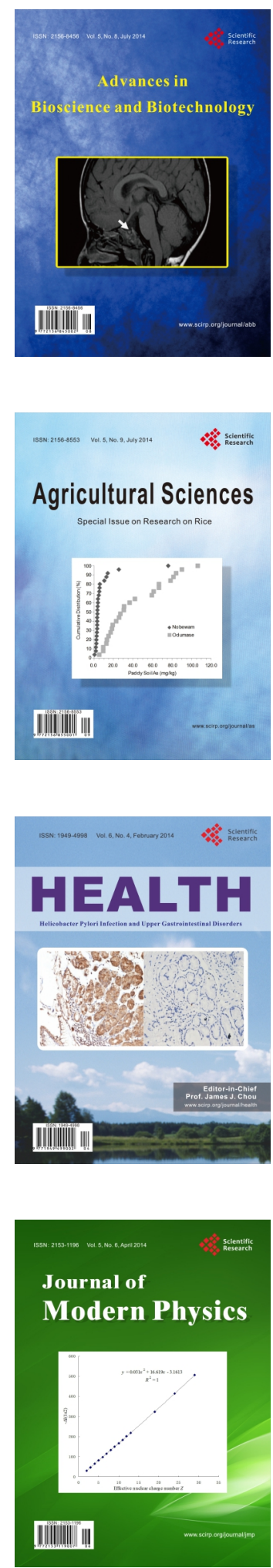
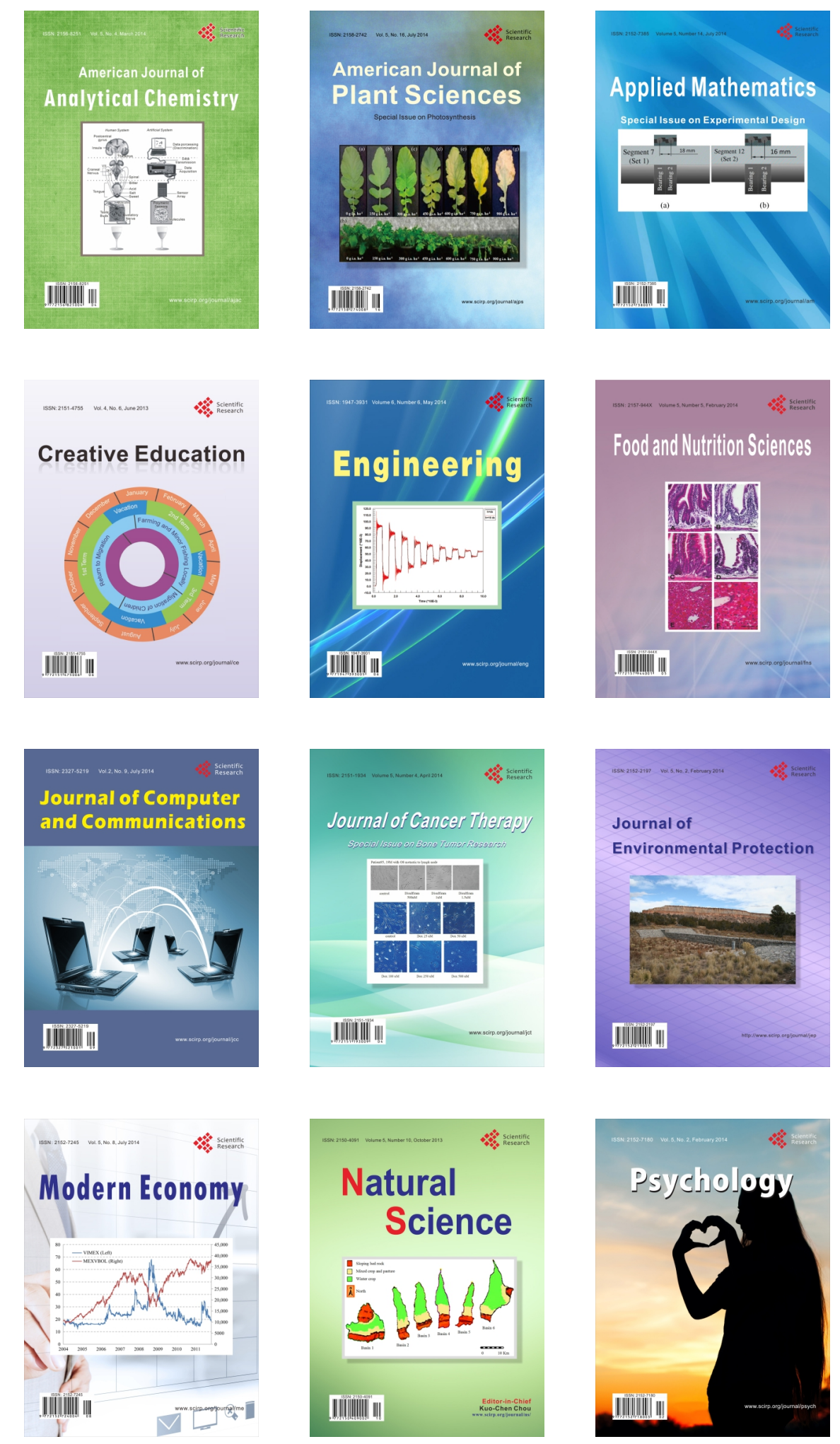